\title{
Analysis of cell proliferation rate in Oral Leukoplakia and Oral Squamous Cell Carcinoma
}

\author{
Sushma Mehkri ${ }^{1}$, Asha R Iyengar ${ }^{2}$, K.S. Nagesh ${ }^{3}$, Bharati M.B. ${ }^{4}$ \\ ${ }^{1}$ M.D.S. Lecturer, Department of Oral Medicine and Radiology. DAPM R.V. Dental College and Hospital, Bangalore. \\ ${ }^{2}$ M.D.S. Professor, Department of Oral Medicine and Radiology. DAPM R.V. Dental College and Hospital, Bangalore. \\ ${ }^{3}$ M.D.S. HOD and Principal, Department of Oral Medicine and Radiology. DAPM R.V. Dental College and Hospital, Bangalore. \\ ${ }^{4}$ M.D. Professor, Department of Pathology. DAPM R.V. Dental College and Hospital, Bangalore.
}

\author{
Correspondence: \\ Department of Oral Medicine and Radiology \\ DAPM R.V. Dental College and Hospital \\ CA-37, 24th main, 1st phase J.P. Nagar, \\ Bangalore -560078 \\ India \\ e-mail address: sushmamehkri@gmail.com
}

Received: 31/05/2010

Accepted: 06/08/2010

\author{
Mehkri S, Iyengar AR, Nagesh KS, Bharati MB. Analysis of cell prolifera- \\ tion rate in Oral Leukoplakia and Oral Squamous Cell Carcinoma. J Clin \\ Exp Dent. 2010;2(4):e173-7. \\ http://www.medicinaoral.com/odo/volumenes/v2i4/jcedv2i4p173.pdf

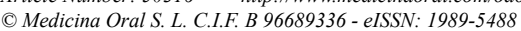

\begin{abstract}
Objectives: Assessment of the cell proliferation rate in tissues can be one of the markers for impending malignancy in precancers. The state of activation and the proliferation activity of the cells can be assessed by the frequency of silver stained Nucleolar Organiser regions (AgNOR) within the nuclei which is significantly higher in malignant cells. The present study was carried out to analyze the distribution of the AgNOR in oral leukoplakia (OL) and oral squamous cell carcinoma (OSCC), and in their various histological grades, and to assess if the AgNOR distribution could give information on the malignant potentiality in premalignant lesions and aggressiveness of the malignant lesions.

Study design: The study specimens comprised of 35 archival cases, of which 15 cases were of OL and 20 cases of OSCC. The specimens were stained by hematoxylin and eosin and modified silver staining method of Ploton et al. for the Nucleolar Organiser Regions. The specimens were analyzed independently by the two observers and was further statistically analysed.

Results: The mean AgNOR count in OL was $2.80 \pm 0.50$ and in cases of OSCC was $5.71 \pm 1.08$. The mean AgNOR count in OL cases of mild dysplasia was $2.59 \pm 0.66$, in moderate dysplasia was $2.92 \pm 0.43$ and in severe dysplasia was 2.79. The mean AgNOR count in cases of well differentiated OSCC was 5.73 \pm 1.62 and in cases of moderately differentiated OSCC was $5.67 \pm 1.19$.

Conclusion: The mean AgNOR count was higher in cases of OSCC as compared to cases of OL, and the AgNOR counts increased with the increase in the grades of dysplasia indicating a higher proliferative rate with increase in dysplasia.
\end{abstract}

Key words: AgNORs, leukoplakia, squamous cell carcinoma, cell proliferation. 


\section{Introduction}

Oral squamous cell carcinoma accounts for over $90 \%$ of oral cancer cases (1) and a small percentage of these cases are thought to develop from precancers like leukoplakia, lichen planus, oral submucous fibrosis etc. There is a striking difference in the incidence and the mortality rates across the world, with highest rates generally registered in a few developing countries including India, Pakistan and Bangladesh, where this is the most common form of cancer. In some parts of the world, including the Indian subcontinent, oral cancer is a major health problem accounting for about $10 \%$ of the estimated new cancers that occur in all parts of the body each year (1). Therefore early diagnosis and management of precancerous lesions and conditions is important. Several methods have been used for the identification of proliferating cells in tissue sections with the aim to use them as a marker for impending malignancy, one among them is Silver binding Nucleolar Organiser region (AgNOR) technique. This is a simple one step staining technique which overcomes the disadvantages of other techniques such as requirement of sophisticated equipment, technical expertise, cost and time consumption $(2,3)$.

Nucleolar Organiser Regions (NOR) are loops of DNA that encode ribosomal RNA and are considered important in the synthesis of protein (4). They are located on the short arms of acrocentric chromosomes - 13, 14, 15, 21 and 22 (5). It has been suggested that the number of
AgNORs in a nucleus may reflect the state of activation and the proliferation activity of the cells (6) and / or degree of malignant transformation of certain tissues (7). The amount of AgNOR is related to the cell cycle, increasingly progressive from $\mathrm{G}_{\mathrm{o}}$ to $\mathrm{S}$-phase and is proportional to the proliferative activity of neoplastic cells (8). A rapidly dividing tumor population is more likely to have a greater proportion of cells in the early stages of $G_{1}$ before individual NORs have associated and are therefore more likely to be observed in greater numbers. Conversely tumors with low rate of cell proliferation are more likely to display a single NOR (8).

The silver staining technique neither identifies rRNA nor rDNA but the acidic proteins associated with these sites of rRNA transcription, these proteins are designated as $\mathrm{B}_{23}, \mathrm{C}_{23}$, 'AgNOR' proteins and RNA polymerase I (9). NORs have recently attracted much attention because of the claims that their frequency within the nuclei is significantly higher in malignant cells than in normal, reactive or benign neoplastic cells (9).

The aim of this study was to assess the cell proliferation rate with the use of the AgNOR technique in OL and OSCC. The objectives of the study were to analyze NOR related parameter in OL and its various histological grading and in OSCC and its various histological grading; and to assess the correlation in the difference between nucleolar organizer related parameters in $\mathrm{OL}$ and OSCC.

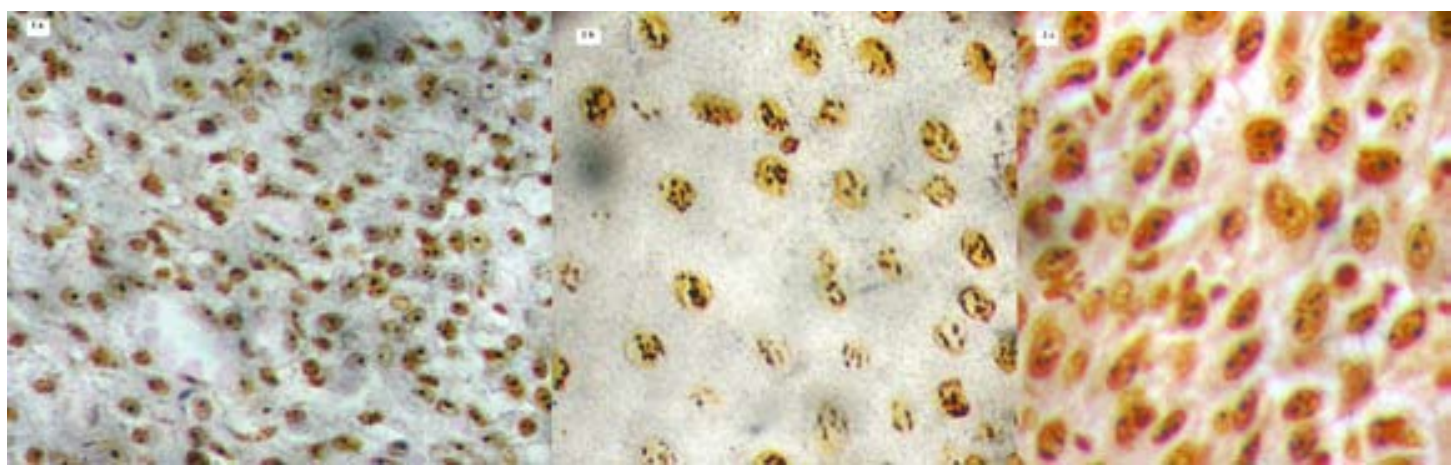

Fig.1. Photomicrographs of silver stained sections of oral leukoplakia (100x) - mild dysplasia (1a), moderate dysplasia (1b) and severe dysplasia (1c)

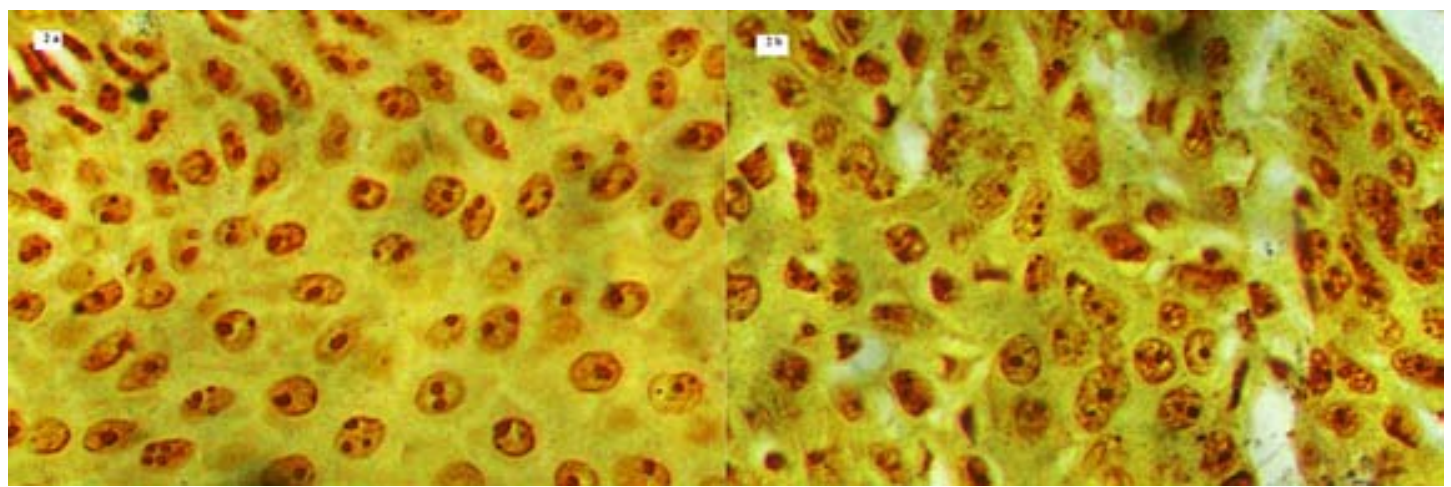

Fig.2. Photomicrographs of silver stained sections of oral squamous cell carcinoma (100x) - well differentiated ( 2 a) and moderately differentiated ( 2 b) 


\section{Materials and Methods}

The archival study specimens were taken from the outpatient subjects of the college Hospital, and comprised of 35 paraffin embedded tissue specimens, of which were 15 specimens of OL and 20 specimens of OSCC. The approval of the ethical committee of the college was obtained prior to the study.

The paraffin embedded tissue specimens were sectioned using a Soft tissue microtome (LEICA RM 2025) and subsequently deparafinised on a hot plate and through xylene, and hydrated through alcohol and subsequently stained with hematoxylin and eosin, and silver stain and mounted on DPX. The enumeration was done under "LYNX N-200M" Trinocular microscope.

The paraffin embedded archival tissue specimens of 15 specimens of OL were grouped histologically as no dysplasia, mild dysplasia (Fig. 1a), moderate dysplasia (Fig. 1b), severe dysplasia (Fig. 1c) (10), and that of 20 specimens of OSCC as grade I (Well differentiated) (Fig. 2a), grade II (Moderately differentiated) (Fig. 2b), grade III (Poorly differentiated).

Preparation of the AgNOR solution was done according to the method proposed by Ploton et al. (11) by mixing 1 part of 'Solution A'with 2 parts of 'Solution B'( Solution $A-2 \mathrm{~g}$ of Gelatin in $100 \mathrm{ml}$ of $1 \%$ Formic acid; Solution B- $50 \%$ solution of Silver nitrate in distilled water). The solution was poured immediately after mixing on the slides and placed in a dark chamber for 40 minutes. The silver nitrate solution deteriorates on standing, so the solution had to be freshly prepared each time before use. AgNOR counting was done as per the method proposed by Giri et al. (5), where in counting of all the specimens was done independently by two observers. 200 cells were counted using a X100 objective, under oil immersion. The number of individually discernable and separable black dots in each nucleus was recorded and the average for each case computed; where two or more dots were so closely aggregated within a nucleolus that the precise number within the aggregate could not be counted, the aggregate was recorded as one. Inter-observer differences were recorded and cases with a difference in excess of one was reassessed. The average of that obtained by the two observers represented the final mean AgNOR count for a given case. This data was further statistically analyzed.

In cases of OL NOR's presented as small round dots which were aggregated within the nucleolus as compared with cases of OSCC where the NOR's presented with larger contours and were dispersed within the nucleolus which could be easily counted.

\section{Statistical Analysis}

The data collected was analyzed independently by two observers and the average of both the values obtained by two observers was obtained for each case, and this was tabulated as the average AgNOR count. The mean AgNOR count and the standard deviation (SD) were calculated in cases of OL and OSCC.

$S D$ was calculated using the formula: $S D=\sqrt{ } \sum \mathrm{d}^{2} / \mathrm{n}-1$

$S D=$ Square root of $\begin{aligned} & \text { Sum of the square of the difference } \\ & \frac{\text { in mean and the individual sample }}{\text { Number of the sample minus one }}\end{aligned}$

The interobserver variation between the two observers was calculated using the "Pearsons Co-relation coefficient" ( $\mathrm{r}$ ) using the formula:

$r=$ covariance between the two variables / product of the standard deviation of the first and the second variable The mean AgNOR values of OL and OSCC were compared using the " $t$ test, for comparing the means of individual samples", using the formula:

$\mathrm{t}=$ ratio of difference between the two means to the standard error of difference between the means.

The mean AgNOR values of different grades of OL were calculated and were compared using the "Analysis of variance" (ANOVA) test, using the formula:

$\mathrm{F}=$ ratio of mean sum of squares between observations to mean sum of squares in observations

The mean AgNOR values of different grades of OSCC were calculated and were compared using the " $t$ test, for comparing the means of individual samples", using the formula:

$\mathrm{t}=$ ratio of difference between the two means to the standard error of difference between the means.

Sensitivity $=\frac{\text { True positives }(\mathrm{TP})}{(\mathrm{TP})+\text { False negatives }(\mathrm{FN})} \times 100$
Specificity $=\frac{\text { True negatives }(\mathrm{TN})}{(\mathrm{TN})+\text { False positives }(\mathrm{FP})} \times 100$
Positive predictive value $=\frac{(\mathrm{TP})}{(\mathrm{TP})+(\mathrm{FP})}$
Negative predictive value $=\frac{(\mathrm{TP})}{(\mathrm{TN})+(\mathrm{FN})}$

\section{Results}

The inter observer variation between the two observers was calculated for both OL and OSCC after calculating the total AgNOR count in each group for each observer using the Pearsons correlation coefficient and was found to be highly statistically significant $(\mathrm{p}<0.0001)$ (Table 1).

\begin{tabular}{|l|l|l|l|}
\hline \multicolumn{1}{|c|}{ Groups } & $\begin{array}{c}\text { Total Ag- } \\
\text { NOR count } \\
\text { observer 1 }\end{array}$ & $\begin{array}{c}\text { Total Ag- } \\
\text { NOR count } \\
\text { observer 2 }\end{array}$ & $\begin{array}{c}\text { Statistical } \\
\text { analysis }\end{array}$ \\
\hline $\begin{array}{l}\text { Oral leukopla- } \\
\text { kia }\end{array}$ & 42.69 & 40.25 & $\mathrm{p}<0.0045$ \\
\hline $\begin{array}{l}\text { Oral squamous } \\
\text { cell carcinoma }\end{array}$ & 114.51 & 109.75 & $\mathrm{p}<0.0001$ \\
\hline
\end{tabular}

Irrespective of the diagnosis $(p<0.0001)$

Table 1. Interobserver variation 


\begin{tabular}{|c|c|c|c|c|c|}
\hline & $\begin{array}{c}\text { Histological } \\
\text { grading }\end{array}$ & $\begin{array}{l}\text { No. of } \\
\text { cases }\end{array}$ & $\begin{array}{l}\text { AgNOR } \\
\text { range }\end{array}$ & $\begin{array}{l}\text { Mean AgNOR and } \\
\text { standard deviation } \\
\text { in different grades }\end{array}$ & $\begin{array}{l}\text { Mean AgNOR and } \\
\text { standard deviation }\end{array}$ \\
\hline Oral leukoplakia & mild dysplasia & 05 & $2.14-3.66$ & $2.59 \pm 0.66$ & \multirow{3}{*}{$2.80 \pm 0.50$} \\
\hline Oral leukoplakia & $\begin{array}{l}\text { moderate dyspla- } \\
\text { sia }\end{array}$ & 09 & $2.45-3.63$ & $2.92 \pm 0.43$ & \\
\hline Oral leukoplakia & severe dyspalsia & 01 & 2.79 & 2.79 & \\
\hline $\begin{array}{l}\text { Oral squamous cell } \\
\text { carcinoma }\end{array}$ & well differentiated & 12 & $3.48-8.55$ & $5.73 \pm 1.62$ & \multirow{2}{*}{$5.71 \pm 1.08$} \\
\hline $\begin{array}{l}\text { Oral squamous cell } \\
\text { carcinoma }\end{array}$ & $\begin{array}{l}\text { moderately diffe- } \\
\text { rentiated }\end{array}$ & 08 & $4.33-8.27$ & $5.67 \pm 1.19$ & \\
\hline
\end{tabular}

Table 2. Histological grades of oral leukoplakia and oral squamous cell carcinoma

Correlation of the mean AgNOR counts in 15 Archival specimens of OL was $2.80 \pm 0.50$ (10 males and 5 females; age range of 35 to 63years) and in 20 archival specimens of OSCC was $5.71 \pm 1.08$ (5 males and 15 females; age range of 41 to 67years). Comparison of AgNOR count in OL and OSCC was done using the " $t$ test" and was found to be highly statistically significant $(\mathrm{p}<0.0001)$.

Comparison of AgNOR count in different grades of OL and in OSCC: The three groups in 15 specimens of OL was compared using the "ANOVA" test and showed statistically no significant results ( $p>0.51)$. The two grades in 20 specimens of OSCC were compared using the " $t$ " test and showed statistically no significant results ( $p>$ 0.97) (Table 2).

Diagnostic validity of AgNOR count in predicting can-

\begin{tabular}{|l|l|l|l|}
\hline $\begin{array}{c}\text { AgNOR } \\
\text { count }\end{array}$ & $\begin{array}{c}\text { Oral squamous } \\
\text { cell carcinoma }\end{array}$ & $\begin{array}{c}\text { Oral leu- } \\
\text { koplakia }\end{array}$ & Total \\
\hline$\geq 3.5$ & 19 & 03 & 22 \\
\hline$<3.5$ & 01 & 12 & 13 \\
\hline & 20 & 15 & 35 \\
\hline
\end{tabular}

Chi-Square $(\mathbf{p}<\mathbf{0 . 0 0 0 1})$

Sensitivity $=19 / 20=\mathbf{9 5 \%}$

Specificity $=12 / 15=\mathbf{8 0} \%$

Positive predictive value $=19 / 22=\mathbf{8 6 . 3 6} \%$

Negative predictive value $=12 / 13=92.31 \%$

Efficiency $=31 / 35=\mathbf{8 8 . 5 7} \%$

Table 3. Cutoff value (95th percentile of Precancer)

cerous lesion in our study was done by establishing a cutoff value, where in a cutoff value of greater than 3.5 AgNOR count can be considered to differentiate between OL and OSCC (Table 3).

\section{Discussion}

The present study comparatively assessed the difference in the cell proliferation rates in the various histological grades of OL and OSCC by the AgNOR technique. The mean AgNOR count was higher in the cases of OSCC as compared to cases of OL, with a statistically significant difference $(\mathrm{p}<0.0001)$ indicating a high proliferative activity in former cases. The mean AgNOR count increased as the grade of dysplasia increased in cases of OL, where as in the cases of OSCC there was no stastically significant difference between well and moderately differentiated OSCC. The AgNOR count has been thought to be a proliferation marker; therefore one would find a difference in normal mucosa, OL and OSCC as reported in literature (12-16).

The inter observer variation between the two observers in our study was highly statistically significant $(\mathrm{p}<0.0001)$ indicating that the AgNOR counting method employed in our study is reliable.

Diagnostic validity of AgNOR count in predicting cancerous lesion was estimated by determining the cutoff value of AgNOR between precancer and cancer. In our study a cutoff value of 3.5 has been suggested, an AgNOR value greater than 3.5 is suggestive of OSCC. In one study the cutoff value of 4.8 was proposed to differentiate between benign and malignant lesions in brush biopsy cases of suspicious lesions of oral cavity (17). In another study a cutoff point of 2.37 was proposed to differentiate between nondysplastic and dysplastic OL (16). Another study proposed that a mean AgNOR count $>2.8$ concurred with poor prognosis in OSCC and that $\mathrm{T} 3$ and T4 tumors $>2.8$ mean AgNOR counts were aggressive and may exhibit resistance to current treatment protocols (12).

The higher AgNOR counts found in many cancers may be due to dispersion of AgNORs in the nucleoplasm, so the AgNOR type may be a helpful in making such a distinction, whether this indicates increased risk of malignant transformation awaits longitudinal study (11). The AgNOR dots in benign lesions shows a large, central, regularly contoured nucleolus containing single or multiple AgNOR dots, where as the malignant neoplasms had multiple small nucleoli with prominent AgNORs distributed throughout the nucleus (5) as seen in our study. As with most histochemical markers of malignant transformation, AgNOR would evidence the metabolic alterations associated with malignant transformation rather 
than characterize malignancy as such (5). AgNORs detect cellular alterations before morphologic expression. In one study the degree of keratinisation and nucleolar activity was assessed in smokers by obtaining cytological smears from the lateral aspect of the tongue using a wooden spatula and endobrush and also evaluated the depth of the cytological smears obtained by the two methods on the lateral aspect of the tongue. The samples were stained with papanicolaou and the silver stain. Smokers with clinically normal mucosa showed a greater percentage of keratinized cells and greater nucleolar activity, and the cytological smears obtained from the endobrush revealed deeper cells, suggesting that cigarette smoking influences the cellular activity of the mucosa of the lateral tongue (18).

In another study the percentage of the number AgNORs present in the nucleus was analyzed, and was proposed that the pAgNOR $>1$ or $>2$ reflects the size of the growth fraction as well as its proliferative activity. This is consistent with the observation that high proliferative activity coincides with poor prognosis. They proposed that the $\mathrm{pAgNOR}>1$ were strong indicators with regard to disease recurrence and short survival in $\mathrm{T} 1$ and $\mathrm{T} 2$ OSCC (14).

In our study two cases of well differentiated (8.55, 8.55) and one case of moderately differentiated (8.27) OSCC showed high Mean AgNOR counts, which were well beyond the Mean AgNOR count of 5.73 \pm 1.62 for well differentiated and $5.67 \pm 1.19$ for moderately differentiated OSCC. The hematoxylin and eosin sections showed high mitotic figures even though they were well and moderately differentiated OSCC. Sano et al. (19) proposed that the 5year survival rate of cases with high AgNOR counts $(\geq 6.5)$ was significantly lower than that of counts $(<6.5)$. Therefore they proposed that AgNOR counts might be a useful marker in assessing the prognosis of the malignant lesion. Based on this proposition the AgNOR counts in our study showing very high values may be marked as having poor prognosis. Therefore the AgNOR method can be used to provide information on the malignant potentiality in premalignant lesions and aggressiveness of the malignant lesions.

To draw substantial conclusions as to whether AgNOR counts indicate increased risk of malignant transformation awaits longitudinal study with larger samples.

\section{References}

1. Gupta PC, Murti PR, Bhonsle RB. Epidemiology of cancer by tobacco products and the significance of TSNA .Crit RevToxicol. 1996; 26: 183-98.

2. Kahn MA, Mincer HH, Dockter ME, Hermann- Petrin JM. Comparing flow cytometric analysis and nucleolar organiser region enumeration in archival oral premalignant lesions. J Oral Pathol Med. 1993; 22:257-62.

3. Kahn MA, Dockter ME, Hermann-Petrin JM. Flow cytometer analysis of oral premalignant lesions: a pilot study and review. J Oral Pathol Med. 1992; 21:1-6.

4. Eslami B, Yaghmaei M, Firoozi M, Saffar AS. Nucleolar organizer regions in selected odontogenic lesions. Oral Surg Oral Med Oral Pathol Oral Radiol Endod. 2003; 95:187-92.

5. Giri DD, Nottingham JF, Lawry J, Dundas SA, Underwood JC. Silver-binding nucleolar organizer regions (AgNORs) in benign and malignant breast lesions: correlations with ploidy and growth phase by DNA flow cytometry. J Pathol. 1989; 157: 307-13.

6. Crocker J, Boldy DA, Egan MJ. How should we count AgNORS? Proposals for a standardized approach. J Pathol. 1989; 158: 185-8.

7. Crocker J, Nar P. Nucleolar organizer regions in lymphomas. J Pathol. 1987; 151: 111-8.

8. Cabrini RL, Schwint AE, Mendez A, Femopase F , Lanfranchi H , Itoiz ME. Morphometric study of the nucleolar organizer regions in human oral normal mucosa, papilloma and squamous cell carcinoma. J Oral Pathol Med .1992; 21: 275-9.

9. Underwood JC, Giri DD. Nucleolar Organizer Regions as diagnostic discriminants for malignancy. J Pathol. 1988; 155: 95-6.

10. Axéll T, Pindborg JJ, Smith CJ, van der Waal I. Oral white lesions with special reference to precancerous and tobacco-related lesions: conclusions of an international symposium held in Uppsala, Sweden, May 18-21, 1994. International Collaborative Group on Oral White Lesions. J Oral Pathol Med.1996; 25:49-54.

11. Ploton D, Menager M, Jeannesson P, Himber G, Pigeon F, Adnet JJ. Improvement in the staining and in the visualization of the argyrophilic proteins of the nucleolar organizer region at the optical level. Histochem J. 1986;18: 5-14.

12. Warnakulasuriya KA, Johnson NW. Nucleolar organiser region (NOR) distribution as a diagnostic marker in oral keratosis, dysplasia and squamous cell carcinoma. J Oral Pathol Med. 1993; 22: 77-81.

13. Pillai KR, Sujathan K, Madhavan J, Abraham EK. Significance of silver-stained nucleolar organizer regions in early diagnosis and prognosis of oral squamous cell carcinoma: a multivariate analysis. In Vivo. 2005; 19: 807-12. Erratum in: In Vivo. 2005; 19: 1141.

14. Sethi P, Shah PM. Oral exfoliative cytology of smokers at discrete clinical stages using AgNOR staining. Indian J Dent Res. 2003; 14 : 142-5.

15. Xie X, Clausen OP, Sudbö J, Boysen M. Diagnostic and prognostic value of nucleolar organizer regions in normal epithelium, dysplasia, and squamous cell carcinoma of the oral cavity. Cancer. $1997 ; 79$ : 2200-8.

16. Chattopadhyay A, Ray JG, Caplan JD. AgNOR count as objective marker for dysplastic features in oral leukoplakia. J Oral Pathol Med. 2002: 31: 512-7.

17. Remmerbach TW, Weidenbach H, Müller C, Hemprich A, Pomjanski N, Buckstegge B, et al. Diagnostic value of nucleolar organizer regions (AgNORs) in brush biopsies of suspicious lesions of the oral cavity. Anal Cell Pathol. 2003; 25: 139-46.

18. Orellana- Bustos AI, Espinoza- Santander IL, Franco- Martínez E, Lobos- James- Freyre N, Ortega- Pinto AV. Evaluation of keratinization and AgNORs count in exfoliative cytology of normal oral mucosa from smokers and non- smokers. Med Oral. 2004; 9: 197-203.

19. Sano K, Takahashi H, Fujita S, Inokuchi T, Pe MB, Okabe H, et al . Prognostic implication of silver-binding nucleolar organizer regions (AgNORs) in oral squamous cell carcinoma. J Oral Pathol Med. 1991; 20: 53-6. 